\title{
THE POLITICS OF UNEMPLOYMENT IN EUROPE
}

\author{
MAURICE MULLARD
}

\section{INTRODUCTION}

In outlining the priorities for the EU at the Florence Summit in June 1996 the President of the Commission Jacques Santer echoed the view of the late Fronçois Mitterand and suggested that reducing unemployment had to become the major policy objective for the Union. Mitterand believed that enthusiasm for the principles of the EU was in decline and had to be regained. Reducing unemployment was therefore essential if the EU was to be of direct relevance to the people of the EU. However, there are major disagreements between the EU strategy for reducing unemployment and that being preferred by nation states. Even at the conference in Florence for example the President of the Commission failed to get agreement to use the projected underspend from agriculture for infrastructure projects, instead nation states preferred to use the funds to reduce their own national public sector deficits. The UK Prime Minister John Major, speaking to The Turning Back Group Conservatives on 3 February 1995 echoed the objectives the Governor of the Bank England. The latter ahd suggested that the EMU criteria which tended to concentrate on monetary policy had also to include unemployment as a condition for economic convergence. Whilst the levels of unemployment do represent a major policy challenge to Europe the central concern of this chapter is whether unemployment as an issue is likely to become a major political priority for Europe in the 1990s. It the unemployed are not to become a major social excluded category from European citizenship the objective of reducing unemployment must become a major policy objective for Europe.

'During the 1970 s, unemployment in the Community crept from $3 \%$ to $6 \%$, but then rose to between $10 \%$ and $11 \%$ from 1983 to 1987 . It dipped to between $8 \%$ and $9 \%$ towards the end of the decade, before rising to $10 \%$ again in 1992 . To reverse this process will require a fundamental revolution in prevailing attitudes of thought and approaches to economy policy' (Grieve Smith 1994p259)

Within the EU at present there are some 20 million unemployed using the ILO/OECD definition of unemployment - this represents about 12 per cent of the European labour force. The problem of unemployment for Europe is not just the rate of unemployment but the persistence and duration of unemployment. Europe has now experienced continuing high levels of unemployment since the early 1980s. It is estimated that the costs in terms of 
unemployment benefits amounts to some $200 \mathrm{bn} \mathrm{ECU,} \mathrm{the} \mathrm{equivalent} \mathrm{of} \mathrm{the}$ GDP of Belgium. Yet this is an underestimate of the real costs in terms of lost production and loss of tax revenues to government. Furthermore, the levels of unemployment are a major constraint on public finances. On a more global perspective the ILO (ILO 1995) estimates that there are now some 86 million people unemployed - a situation which is both morally and economically unsustainable.

At one level it seems paradoxical that unemployment in the 1990s continues to be a major challenge for Europe taking into consideration the optimism which surrounded the completion of the Single European Act (SEA) in 1987. Both the European Commission and the Cecchini Report (1988) were then able to emphasise that the completion of the Single European Market in 1992 would result in an increase of the GDP of th EU. This increase of 200 bn ECU equivalent to 7 per cent increase of the EU GDP was likely to reduce EU unemplyment by 5 millon as the Commission noted at the time.

Among the various indicators of success (of SEM), the most crucial today is that relating to employment (Commission $1988 \mathrm{p} \mathrm{166).} \mathrm{This} \mathrm{view} \mathrm{was}$ reinforced further in the Cecchini Report which stated, that 'perhaps most important of all, is the medium term impact of market integration on employment. With its injection of inflation free growth, coupled with a loosening of the constraints on public exchequers in the Community' member states, the European home market of the 1990s raises the prospect, for the first time since the early 1970s, of very substantial job creation' (Cecchini 1988, XIX).

The SEA (Single European ACT) committed member states to the free movement of labour, goods, capital and services. The single market committed governments to removing barriers and subsides and to allow for increases in trade and competition. Those in favour of the SEM pointed out that this would reduce the costs, to companies in terms of transaction costs bureaucracy and delays. Furthermore the phasing out of state subsides to industries would provide governments with additional finances which could be used to reflate their economies. Finally, it was pointed out that competition would increase consumer choice, reduce costs and prices and reduce inefficiency.

What is crucial to remember is that the European Commission was aware that the SEA was likely to result in job displacements and re-structuring because of the presesures of competition. However the SEA over the medium term was likely to result in a net increase of 1.8 million new jobs. This figure though would not be sufficient to bring about any significant reduction in the current unemployment figure, since the unemployment rate would fall by only 1 to 2 per centage points in the medium term, (Commission 1988, p162). However essential to the Commission's argument was the added commitment by government to re-direct public expenditures from subsidies to fiscal policy. It was the policy of fiscal co-ordination which was likely to result in an increase of 5.2 million additional jobs. 
Asking what went wrong with the Commission's prediction on SEM in 1988 leads to two types of answers. First it might be argued that the studies conducted by the Commission in 1988 tended to be over-baised towards SEM and the studies therefore produced the result the Commission was looking for (Neuberger 1989, Cutler 1989). In this context the studies overestimated the benefits of SEM and did not take into account problems of consumer taste and market fragmentation.Furthermore increased competitiveness was more likely to lead to job losses, the downsizing of companies and labour market readjustment. The Commission had tended to assume that people displaced in one industry would be absorbed in another sector. Secondly it might be argued that the Commission was over optimistic on the extent to which there would be political willingness amongst governments to expand their economies through fiscal policies. The Commission assumed that a Keynesian economic consensus still existed when most countries had already embraced the economics of market liberalism and monetarism.

Unemployment since the 1980s has not been of major political concern. Governments have succeeded in holding on to office despite the high levels of unemployment. This has be contrasted to the 1960s and 1970s when increases in unemployment were seen as morally and politically unacceptable. In the 1980s high levels of unemployment became politically tolerable and government became increasingly complacement- unemployment reduction was no longer a major policy objective. Governments became involved in the politics of contentment (Galbraith 1993) which meant that as long as government ensured that they protected or increased the living standards of the working majority the unemployment would not become a political threat.

\section{RECESSION AND DEPRESSION IN THE 1980s AND 1990s}

In 1996 Germany recored the highest rate of unemployment since 1948. In that year unemployment reached $4,4 \mathrm{~m}$. By contrast in 1996, the unemployment rate in the UK had fallen to 2.2 million or 8 per cent of the total workforce. In West Germany between 1973 and 1980 some 900,000 jobs were lost in manufacturing and engineering, and 500,000 in agriculture, whilst the total working population fell from $26.6 \mathrm{~m}$ to $25.8 \mathrm{~m}$. In the UK the shake out of the early 1980s resulted in a loss of $2 \mathrm{~m}$ jobs in manufacturing. France has endured the longest period of mass unemployment. Here unemployment has not fallen below 10 per cent since the mid 1980s. In 1996 the unemployment rate in France rose 3,3 million which represented 13 per cent of the total workforce despite the fact that the economy has expanded by $2.5 p e r$ cent during that year. The government of President Chirac elected in 1995 has tried to use capital expenditure on housing, and subsidies to employers during 1995 in order to raise employment fugures. But the policy was revered in 1996 as the government tried to regain control over public expenditure in order to meet the EMU critieria in 1997. 
Since 1984 a neo classical discourse has become increasingly the paradigm in Europe. There has emerged a widespread view that Europe. Because of age and tradition, conditions of work were not changing fast enough to meet the challenges of a changing economic context when compared to the more flexible labour markets of the US and Japan. The implicit agenda seems to indicate that Europe needs to expose labour markets to competition and emulate US supply side economics. One often cited statistic for example, suggested that the whilst in the US between 1972 and 1990 real wages had grown by 0.4 per cent a year, real wages in Europe had grown by 1.5 per cent a year. As a consequence it is argued that during the same period the US was able to create 8 million new jobs, whilst in Europe there had been no increase in the labour force participation rates. There is however a small caveat, whilst the US had the most de-regulated labour market and low unionisation during the 1970s the US unemployment rates was continuously higher to that of Europe secondly that the employment gains since 1986 were secured primarily through the proliferation of low paid, low productivity, part time service sector jobs (Applebaum and Schettkat 1991).Accordingly it was argued that unemployment in Europe was the result of workers pricing themselves out of jobs, and what government needed to do was to remove rigidties from the labour market and make the labour market more flexible.

Most countries seem to have accepted the new language of competitiveness. Germany has produced easier rules on unfair dismissal whilst France eased procedures on hiring and firing restrictions combined with reducing unemployment benefits. The Netherlands introduced reforms on redundancy and unemployment benefit cut. Belgium has reduced the period for dismissal notices, In the UK the Government produced a series of trade union reforms, cut back social security, reduced income taxes and emphasised a policy which sought to improve the supply side of labour markets.

Whilst unemployment did increase in most of the EU countries since the early 1980s, there were differences both in the way unemployment was experienced and handled in different countries. UK unemployment in 1982-83 reached 3.3 million or 14 per cent of labour force, whilst unemployment in Germany also increased but not at the same rate - never going beyond 8 per cent. Taking the period 1979 to 1994 into account only Ireland and Belgium recorded higher levels of unemployment than the UK. Whilst all European countries experienced two recessions between 1980 and 1992, the recessions in the UK were always deeper. 


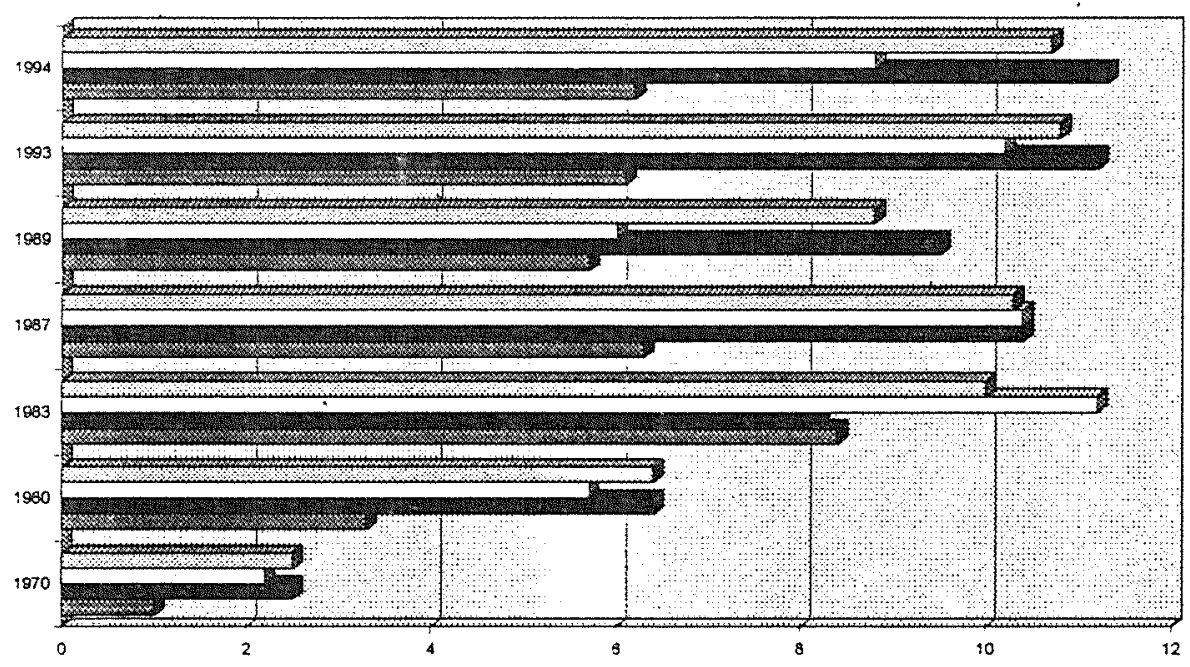

\section{Unemployment in Germany France UK and Europe 1974-1994}

A number of explanations have been given about the nature of unemployment in Europe. These have included arguments about the relationships between unemployment and wage costs in Europe when compared with the US and Japan, and also the relationship between unemployment and non labour costs. Throughout the 1980s and early 1990 s whilst wage costs in the US remained either stationary or declined, wages in Europe continued to expand. In the meantime the US has created more jobs than Europe. Both the EU and OECD have suggested recently that Europe needs to reduce its labour costs. There is however a different lesson to be learned from the US experience. Whilst the European countries continued to reduced their public sector deficits in the $1980 \mathrm{~s}$, reducing it by 5 per cent, unemployment in Europe continued to expand, However, the US increased its public sector deficit and also managed to keep employment stable. 


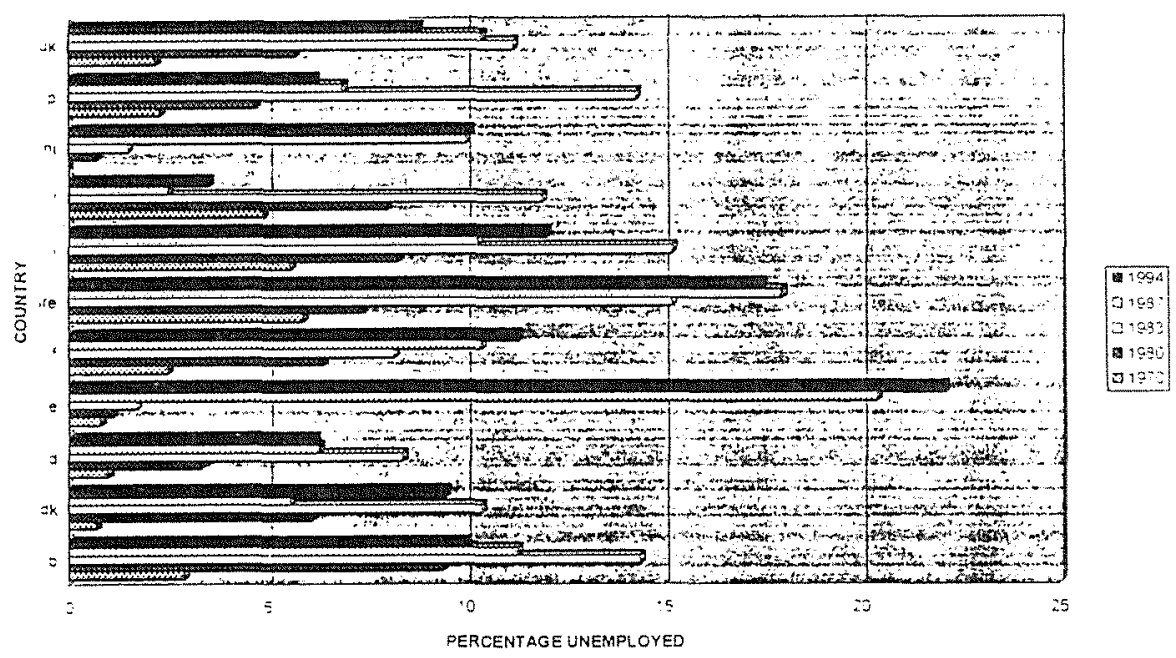

\section{Unemployment in Europe 1970 - 1994}

Whilst other studies (Bean 1993) Romer(1993) Teague (1994) have sought to locate explanations of unemployment within the perspectives of New Keynesianism and De-Regulated Labour Markets (Teague 1994) this chapter seeks to outline four major perspectives of unemployment. The major difference is that this paper seeks to draw out the issues of trade unions, collective bargaining and corporatism and into the category of institutional explanations. Other authors alternatively have put these explanations within a New Keynesian perspective. Finally this paper also provides a structural perspective which is separate from the concept of markets and de-regulation.

\section{THE NEO CLASSICAL VIEW OF UNEMPLOYMENT}

According to this approach the major causes of unemployment are due to rigidities in the labour market, and governmental inability to provide reforms which are likely to improve both the demand side and labour supply. The Neoclassical view is mainly associated with the work of Friedman and Minford, and the dual concepts of the natural rate of unemployment and the non accelerating inflation rate of unemployment (NAIRU). The argument in a nutshell is that any attempt by government to reduce the natural rate of unemployment is likly to be dissipated in higher inflation. The natural rate of unemployment is not stable but moves according to change in labour costs, and as labour costs increase the natural rate of unemployment is therefore also likely to increase. If the government wants to reduce the natural rate of unemployment than it has to reduce labour costs, such policy however cannot be achieved without a policy that succeeds in curbing inflation, since it is inflation which influences wage bargaining and also increases non wage labour costs. 


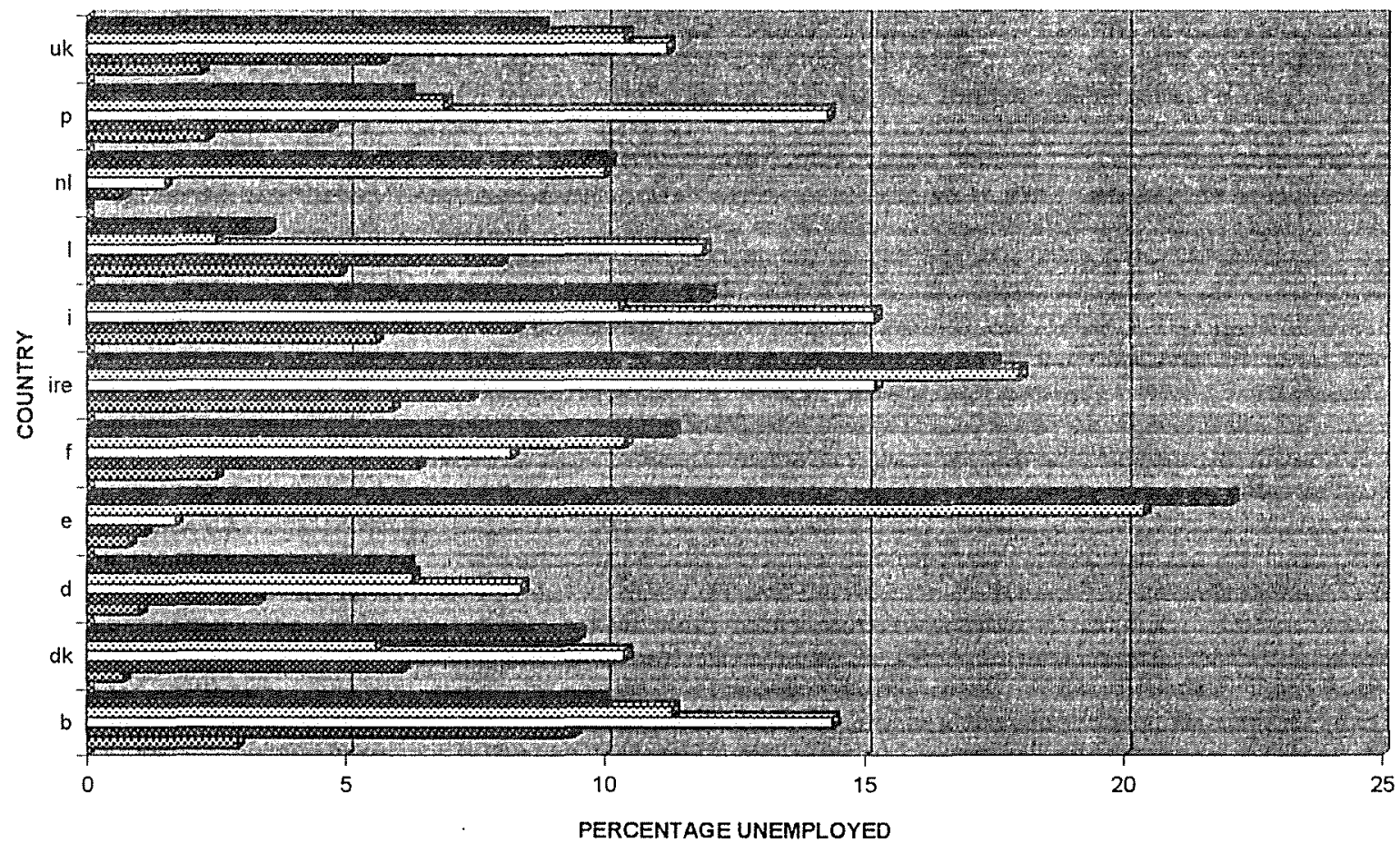




\section{DEMAND SIDE}

Demand for labour depends on the costs of hiring labour, and these include both direct and indirect labour costs. Direct labour costs include wage costs and employers contributions to social protection. Employers it is argued will hire more labour at lower labour costs and therefore the role of government is to provide a climate in which labour costs can fall. This raises the question of why labour costs rise, which in turn lead to research into the relationship between inflation, unemployment and government expenditure. According to Rational Expectations prospective workers as rational agents, bargain on wages according to the excepted rate of inflation. If inflation is likely to rise in the future then workers will bargain to obtain wage increase which offset inflation. Workers as rational agents know that increases in government expenditure and higher levels government borrowing are likely to be inflationary. They therefore bargain for wages accordingly thus offsetting any attempt by government to increase employment through demand management.

Accordingly a neoclassical view demand management policy will not succeed in reducing unemployment since this is likely to be inflationary. Improving the demand side for labour will succeed if there is reduction in labour costs either through falling wages, or higher levels of productivity or lower non wage labour costs. The policy agendas implicitly includes reducing employers costs on national insurance, and reducing taxes, to allow workers to increase their take home pay without putting pressures on wage costs.

\section{SUPPLY SIDE ECONOMICS}

Reform of the supply side includes four areas of reform

(a) Trade UnionReform

The raison d'être of trade unions is to restrict labour supply since only by restricting labour supply can trade unions influence wages. Government needs to reforms trade unions, removing trade union immunities and thereby creating a more flexible labour supply side.

(b) Social Security

High levels of social security payment provide a disincentive to work, and increases the duration of unemployment as workers tend to spend more time in job search. If governments want to reduce unemployment duration then it needs to provide lower levels of social security payments. A typical example of the association between the provision of welfare and employment is as outlined below by Anthony de Jasay in the Financial Times on 20 January 1994 (A vicious circle of social kindness). Unemployment in Europe where the welfare system is more costly per head is twice as high as in the US and many times higher than East Asia.

According to De Jasay the welfare state as a form of social protection is not well explained. People feel that others are paying for social protection, whilst at the margin the cost outweight the subsidy. Unemployment is born out of social protection and as unemployment increases taxes also increases which 
leads to further unemployment. S Brittan has also argued that workers do not take into consideration the social wage in their bargaining with employers. Crossland also argued that attempts to finance welfare expenditures through higher taxes is likly to lead to higher inflation since workers seek to compensate for their loses in disposal income without taking into account any improvements in social wage.

In contrast Ms Vasso Papandreu in her attempt to promote the Social Chapters pointed out that: "We have a moral obligation to set minimum standards in order not to allow market forces or wild capitalism to function at the cost of workers. If we want to have the kind of societies they have in South East Asia, then we should do that openly. But I don't think that's acceptable at the European level" (Interview with FT 29 Nov 91 Greek Socialist Flying workers flag).

\section{DISCRIMINATION IN LABOUR MARKETS}

Both gender and race discrimination also influence labour supply and governments needs to provide anti discriminatory frameworks which will improve labour supply and also allow wages to fall. The European Unemployment Programme came to the following conclusion in 1987, "The major problen in Europe is that productivity gains are quickly absorbed into wages and the effect of unemployment on wages settlements is generally weak'.

Europe does suffer from a different degree of labour market rigidifies, and whilst prices and wages do change, this is not fast enough to create market clearing conditions for unemployment to fall. Secondly, Europe is more inflation prone due to the wage price spiral. Thirdly Europe is also more vulnerable to external economic environment in contrast to US which is in a more monoploy position.

An examination by Ormerod (1994) on the relationship between inflation and unemployment led the author to conclude that the concept of NAIRU was deeply flawed and that there was at most a very weak relationship between th twin variables of inflation and unemployment. For example studies in Europe confirmed that in only three countries was there the anticipated negative sign between unemployment and inflation, and in only one country was the result significant at the 5 per cent level. The studies show also that higher inflation reduces unemployment.

\section{KEYNESIAN DEMAND MANAGEMENT}

The core assumption associated with a Keynesian view of unemployment is that unemployment exists because of a decline in overall demand. This argument suggests that since the early 1980s governments in Europe made the control of inflation their major policy objective without thinking of the implications for unemployment. It is an argument which suggests that governments tended to accept the monetarists view which pointed out that 
reducing demand through the control of the money supply at no cost output. The move towards EMS convergence in the early 1980s as a means of controlling the money supply meant that countries had to increase interest rates irrespective of the conditions of the domestic economy, which eventually led to higher interest rates and overvaluation of European currencies. The over valuation of currencies in the UK, France and Ireland made these economies less competitive and accelerated the rate of unemployment.

The 1980s also saw the phasing out of Keynesian demand management. The reponse to the oil prices shocks of $1972-73$ and 1980-81 resulted in governments pursuing more national economic policies rather than policy coordination with a number of countries. The result meant a monetary policy, high interest rates and the downgrading of fiscal policy. Both the UK Labour Government in the 1970s, and the Mitterand Government in France during the early 1980s soon found they could not go for expansion to reduce unemployment.

Commenting on the recession of the early 1980s Layard concluded that policies in the 1980s have therefore tended to be deflationary. Until this deflation of demand is moderated, the hopes for unemployment are poor. For the quickest way to raise employment is to spend more now, and accept that inflation will continue at the present level. (Layard 1986 p33)

The criteria outlined for EMU are likely to lead to further deflation as countries continue to reduce budget deficits and inflation rates to meet the convergence criteria by 1997 . This approach to convergence suggests that at minimum, governments in Europe will continue to make inflation their major policy objective without thinking about the consequences for employment. This for the foreseeable future the high levels of unemployment in Europe will continue.

\section{STRUCTURAL EXPLANATIONS}

According to this view, unemployment in Europe needs to be located within the wider context of changes in the global economy. This approach points to the limits of Keynesian demand management suggesting that any changes in demand have little impact on structural or 'Hard-core' unemployment (Brittan 1995). One major structural change has been the dislocation in manufacturing, where Europe has lost some 5.5 million jobs since 1981, whilst not being able to repalce these jobs in the service sector. The decline in manufacturing employment confirms that since 1980 EC manufacturing employment which fell from 28.9 per cent of the total workforce to 24.4 percent in contrast to the US decline from 22.8 per cent to 19.1 per cent, and Japan from 25.5 per cent to 24.7 per cent. The study also confirms that the major job losses in manufacturing took place in the UK which lost a total of 2 million jobs which also makes up 40 per cent of the total jobs losses in Europe. Aldocroft (1993) has argued that Europe in the 1980s experienced Jobless growth, in that though the Economies in Europe did continue to expand throughout the 1980s the new prosperity did not lead to increases in employment. 
'Jobless growth therefore seems to have been a peculiar feature of the major Western nations. Estimates suggest that a rate of growth of around 2-2.5 per cent a year is required before employment responds positively. Thus on the basis of a continuation of growth rates of around 3 per cent a year, as experienced in the late 1980s, and a labour force growth of 0.4 per cent a year, unemployment levels would continue to remain high, around 6 per cent, through to the mid 1990s. In other words, a return to the former low levels of unemployment of the post-war years would require much higher rates of economic growth than have been the case over the last few years' (Aldcroft, 1993, p235).

In the context of the experiences of the 1990s it would seem that Aldcroft's predictionis rather too optimistic. The author did not predict the recession of the late 1980s. Europe did not continue to experience growth rates of 3 per cent a year, in fact growth fell to 1 per cent a year for the years 1989-1992 which has left Europe with unemployment levels of 10 per cent and not 6 per cent as Aldcroft predicted.

However, the problem with the structural perspective is that it tends to provide a snapshot of the here and now. Peter Robinson (1994) has suggested that most of the structural changes have now been taking place for nearly 40 years. There has not been for example a dramatic increase in part time employment in the $1980 \mathrm{~s}$. In fact the expansion in part time employment has actually slowed down in the 1980s when compared to the previous three decades. Furthermore there has not been an expansion in low paid employment, but more of an expansion in the professions and managment.

THE STRUCTURAL PERSPECTIVE IS ASSOCIATED WITH THREE BROAD STRATEGIES

(a) A do Nothing strategy. This is an argument which suggest that government cannot influence the global economy. Manufacturing is now firmly located within the emerging Asian Tigers against whom Europe cannot compete. The jobs losses in manufacturing are permanent and Europe has therefore to adjust to this structural change by providing social security benefits to those whose lives have been disrupted. It is an approach which suggest that governments should abandon policies of economic growth since such policies are no longer environmentally sustainable. Furthermore it is an approach which suggest that governments should concern themselves more with redistribution and educating people for life.

(b) Investment in Human Capital by providing training or education to ensure that people are absorbed into new sectors. People who are vulnerable to unemployment are those with low skills. Governments need to provide opportunities for reskilling and the upgrading of skills of the present workforce. Jeremy Rifkin (1995) "The End of Work" has argued that the impact of new 
technologies, computerisation, telecommunications, and robotics have made millions of jobs redundant. Retraining in new skills is therfore a myth since the jobs no longer exist.

(c) State promotion of new investment in new technology industries improved European communications including the trans European network supporting high technology projects which keep Europe at the forefront of research.

(d) A social cohesion fund to provide additional funds to regions which experience high levels of unemployment to bring about adjustment and structural change

\section{INSTITUTIONAL APPROACH}

There are a number of strands to this approach, but there are a number of core assumptions which seem to constitute the home domain of an institutional perspective. According to an institutional perspective the aim is to explain differences rather than similarities so that although there is a problem of unemployment in Europe the problem is not experienced similarly in all countries. Throughout the 1980s compared to other European countries Sweden experienced very low levels of unemployment. Unemployment in Sweden during the 1980s was similar to the levels of unemployment in Europe during the 1960s. Whilst France, the UK, Belgium, and Italy experienced mass unemployment- UK exceeeding 10 per cent of the workforce most of the 1980s, German unemployment peaked at 8.5 per cent.

According to Therborn (1986) the major factor which seeks to explain the divergence in unemployment has been the extent to which the commitment to full employment has been institutionalised within the political process.

The existence or non-existence of an institutionalised commitment to full employment is the basic explanation for the differential impact of the current crisis' (Therborn, 1986, p 23).

Therborn defines an institutionalised commitment to full employment as follows:

1. The commitment to full employment is an explicit policy objective of government. A number of governments produced a series of White Papers in the immediate post war settlement which indicated a serious commitment to full employment (Apple).

2. The commitment of government to use fiscal and monetary policies to counter the economic cycle.

3. To intervene in the labour matket to ensure full employment including an incomes policy creating public sector employment.

4. A conscious decision by governments not to use high unemplyment as a means of containing inflation. 
Korpi (1991) has also argued that the dominace of left parties in government have created 'societal' forms of bargaining arrangements between employers trade and government which have contributed to holding down the levels of unemployment especially when compared to those countries which committed themselves more to free markets and deregulated labour markets.

Layard has for example argued that the reform of trade unions in the 1990s and the move towards decentralised pay bargaining have increased the pressures of inflation. A point taken up by both Robinson (1994) and Metcalf. Layard's argument is that the move towards decentralised bargaining has again rekindled problems to leap-frogging in wage bargening similar to those experienced in the 1960s and 1970s. Trade Unions are again ensuring through the process of decentralisation to maintain their position in the wages league.

The work of Cormfill Drifill (1988) and Freeman (1988) seems to provide supporting arguments for a hump theory of corportatism. Their argument suggests that labour markets have performed better in those economies associated with high centralisation and those which have complete forms of decentralised bargening. Both models they suggest provide the required flexibility in wages to ensure minimun job losses. In countries which are neither completely market based nor corporatist tend to perfurm less well. Within these environments neither workers nor employers are committed to the maintenance of full employment. Workers pursue sectional interest through their trade unions - pay bargaining is characterised by leapfrogging and wage drift. Workers seem to accept the axiom of the market without taking into consideration the implications of their actions for employment.

The problem with both these studies is that they seek to give the expression to the concept of corporatism is in place by proving a measure or proxy variable for corporatism. The problem is that corporatism as a concept is associated with a different meaning. It includes ideas of centralisation in wage bargaining but it also includes participation in decision making by strategic groups. Corporatism exists also at many levels, at the level of industry, sector, region or the in macro economy.

The institutional perspective can be described as Keynesian plus Institutional Economics. It is a perspective whcih recognises that Keynesian economics alone cannot maintain full employment without other policies which seek to deal with wages and inflation. It is a perspective which is associated with the concepts of consensus building, social partnerships and dialogue as being the alternatives to the impersonal workings of the market economy.

\section{THE CONVERGENCE OF LANGUAGE}

One of the safest assertions that can be made about the 1980s and early 1990 s is that there has been a major shift in economic policy making both at the intellectual and the practical levels. At the intellectual level there has been 
a paradigm shift from the Keynesian consensus of the post war to a more market and Neo classical perspective, which has had major implications for evaluating policy options and the making of policy.

This shift in ideas has also had a major influence on policy making institutions at the level of national government, Europe and international institutions. A close study of documents produced recently by the OECD and the EU reinforce to a degree the idea that governments have come to accept the lanuage of the NEO classical, and the view that there is need to deregulate labour markets as the major policy instrument to reduce unemployment. John Grieve Smith came to the following conculsion in his assessment of recent OECD policy prescriptions.

"Much of the play made with debt ratio etc, is really based on antagonism towards the growth of public expenditure as such, and nothing to do with the real problem of public finance. The December 1992 OECD Economic Outlook gave the game away by holding up the present New Zealand government's dismantling of the welfare state as "the leading example of how to improve the efficiency and effectiveness of all forms of public spending". It is unfortunate that this sort of political prejudice from an established international organisation should overlay any attempt to distinguish where, or to what extent, growing public debt could be a significant problem' (Grieve Smith, 1994 page 270).

In their recent study the OCED (1994) urged governments to reduce costs including welfare costs, improve incentives, and phase out subsides to certain sectors. The OCED seems to have accepted the view that the levels of economic activity and employment are unaffected by fiscal policy and therfore tend to perceive public sector deficits as structural deficits.

The European central bank governors report of April 1993 called for measures to reduce state spending or increase taxes to avoid the risk of overburdening monetary policy. The Report did not seek to evaluate the impact of further reductions in public expenditure or increases in taxes. Instead the report came to the conclusion that the only policy objective was for governments to reduce interest rates that they could only do this if they reduced public sector deficits. The EU (1993) White Paper "Growth Competitiveness employment The Challenges and Ways Forward into the 21" makes the following remark,

"At the end of the 1980s was the economy was growing strong unemployment stood at $12 \mathrm{~m}$. The explanations for the rigidty of unemployment are now clear. The relative high costs of unskilled labour is speeding up the rationalisation of investment and holding back job creation in services. This has resulted in the loss of millions of Jobs' (EU, 1993, page 11).

The EU White Paper pointed out that in Spain and Germany growth rates had been in the range of 2 to 3 per cent per annum over the last 15 year yet unemployment ranged between 6 to 16 per cent. In contrast growth rates in UK and France had between 1.8 and 2.5 per cent annum yet unemployment 
stayed around 9 per cent. The EU concludes that growth was no longer the solutaion to unemployment, and that therefore unemplyment in Europe was structural.

Furthermore, the EU White paper comes to similar conclusions to the Central Bank Report when making suggestions for macro economic policy. The strain needs to be taken away from monetary policy so that room is made for the reduction of interest rates. Hard core unemployment is among male unskilled workers. The reason for the displacement of unskilled workers is the high cost of labour in Europe when compared with that the US and Japan. Another major element is non wage labour costs in Europe.

(Annual report 1993 of the Committee of EC Central bank governors Bank of International Settlemants Basle Switzerland)

\section{Comparison Statutory costs in Europe}

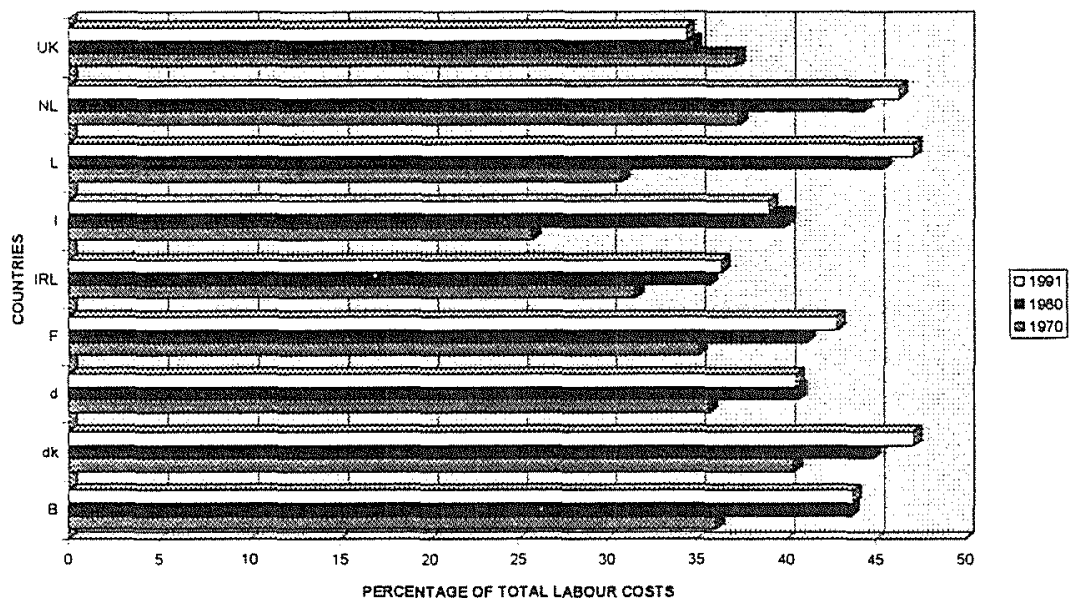

Between 1970 and 1991 statutory charges in Europe, which includes taxes and social insurance contributions, increased from 34.4 per cent to 39.6 per cent. In contrast in the US costs remained stable at 29 per cent. In Japan statutory charges did expand from 19 per cent in 1970 to 30 per cent in 1992 but this is still well below the European average. In Europe only the UK has reduced its non labour costs from 37 per cent in 1970 to 34.4 per cent in 1992.

In an alternative language to that of the International Bankers, the IMF, the EU and the OECD, the recent ILO Report argues that the present strategies will continue to have deflationary implications for the global economy with no hope being offered to the unemployed. The ILO argues that the attempts to deregulate markets, the attempts to minimise the role of trade unions and the move away by governments from fiscal policy do not provide the foundations for better employment opportunities. The ILO points to countries which have been more interventionist as having better employment records. 


\section{CONCLUSION}

In dealing with unemployment there seems to be a widening gap between the rhetoric of policy statements and the reality of policy implementation. Whilst all governments in Europe would agree that unemployment possesses a major Challenge the policy options confirm a high degree of complacency. The determination by policy makers to deal with unemployment does not match the determination to deal with inflation, budget deficits and public expenditure. Governments have adopted deflationary monetary policies without evaluating the consequences for unemployment.

'The deflationary monetary policies adopted in many European countries in the 1980s were the results of the constraints of ERM membership, and they could help to provide an explanation for the rise of unemployment throughout Europe' (Barrell 1994 p35).

In the aftermath of World War 2 governments committed themselves to full employment within a context of a devastated European Economy. At both national and international levels there was the political will to utilise fiscal policy accompanied by commitments to policy co-ordination on exchange rates, and creating social partnerships at the national level which made the commitment to full employment a possibility. By contrast the response to the oil price shock of the 1970s was to dismantle Bretton Woods to move to floating exchange rates and to make individual countries more vulnerable to speculative risk. Within the context of a global monetary economy individuals countries have tended to deflate their economies to avoid speculative risks against their individual currencies.

A commitment to full employment in Europe cannot be achieved through fiscal expansion by individual countries. Both the UK and French attempts to go it alone confirm the limits of such a policy. At a European level policy coordination has to involve the move away from floating exchange rates to a more fixed exchange rate regime. The commitment to EMU could provide the climate for a stable exchange rate regime where countries in Europe will not have to compete in ratcheting up their interest rates to avoid currency speculation. Exchange rate stability together with stable interest rates could provide the framework for fiscal expansion, provided that countries pooled their external balances within a European context.

The arguments for EMU and single currency should not over emphasise the advabtages of reducing transactions costs. The question is whether EMU will provide the necessary mechanisms for the co-ordination of monetary policy. A policy which would minimise speculative risks against any single currency and which would allow countries to reduce interest rates and move away from deflationary policies.

Outside Europe there are at least three altenative approaches to reducing unemployment. First there is the US Free market model. The US has a highly deregulated labour market, low trade union density, and a record of high job 
creation when compared with Europe. The willingness of the Reagan and Bush administrations to expand budget deficits while encouraging a flexible labour market helped to expand employment participation. In 1995 the US unemployment rate was 6 per cent of the total labour force in contrast to 10 per cent in Europe. One consequence of the US has been the widening wage disparties between the top ten per cent of earners and the rest, and also the lack off improvement is real wages over the last decade. A Second model is offered by Japan with its highly regulated approach to the market economy and the willingness of government (through MITI) to intervene in industry to ensure continuing investment in new technology industries. Japan offers a unitary approach to industrial relations with companies seeking to secure the loyalty of core employees though their employment for life approach. The third model is that offered by the Asian Tigers with their commitment to business corporatism combined with low wages, low government expenditure, and low inflation.

At a European level there are two possible alternatives. First there is the Deregulated market approach associated with the Neo classicals, the model being offered by the USA and the UK. This approach suggests there the priority should be removing labour market rigidities. This implies a strategy for lowering labour costs to make Europe competitive in the context of glodal economy. In the UK of the 1990s people are working longer hours for lower wages. There has been major increases in productivity together with a shift from direct to indirect taxes. Non statutory labour costs in Britain have continued to fall over the past decade in contrast to the rest of Europe where costs have continued to increase. Despite these measures the UK has experienced deeper and longer recessions in the 1980s. The flexible labour market has led to easier hiring and firing policies which means that during the early part of a recessions more workers tend to lose their jobs although they are reabsorbed early at the beginning of the recovery cycle. The increased casualisation of the labour market means that there is reluctance by employers to invest in the human capital of their employees.

The European model is founded on the concept of consensus building, institutionalised bargaining together with a commitment to full employment. The model of the social market is seen as making a major contribution to the German economic miracle of the post war. Variants of this model have operated in the Nordic countries and attempts have been made in France and the Netherlands to move towards a consensus builing model. German unemployment which peaked at around 8.5 per cent continues to be lower than that of the UK, Belgium, Ireland or Italy.

At present the European corporatist model also seems to be coming apart. In Sweden the new Government of Carlsson has come under immense pressure from the financial sector to produce policies which seek to reduce the fiscal 
deficit. Since November 1995 the Swedish Governments have announced expenditure for the next three years amounting to $£ 12 \mathrm{bn}$ in the hope that the government reduces the PSBR from 13 per cent to 7 per cent. Within the context of EMU the Swedish government will come under pressures to reduce its deficit further if it is to meet the Maastricht convergence criteria. In Germany employees are asking the government to reduce non labour costs. Germany is coming under pressure from the emerging Eastern European states especially from the Czech Republic which has a highly skilled labour force and low wages. Increasingly German employers are moving towards a UK view of competitiveness and are seeking to break with national bargaining and are asking government to secure reductions in the social security budget.

All these models offer only limited lessons. Europe has a tradition of a commitment to state welfare and the incorporation of both business and trade unions in economic policy making. The question is whether Europe in the context of a global economy has inevitably. To compete with the Pacific Rim and Eastern Europe by encouraging workers in Europe 'to compete' through reducing wages and non wage labour costs or can Europe compete and provide employment combined with high quality welfare and high wages?

\section{References}

ALDCROFT D., (1993) The European Economy 1918-1990, Routledge, London.

BARRELL R., (1994) Prospects for European Unemployment in Grieve Smith and Michie. BEAN C., (1993) European Unemployment: A Review of Competing Explanations, Journal of Economic Literature No 34 pp 604-654.

BRITTEN S., (1995) Capitalism with a Human Face Edward Elgar, Aldershot, Hants

Callmforms L and Driffill J., (1988) Bargaining Structure, Corporatism and Macro Economic Performance, Economic Policy pp 635-662.

CECCHINI P., (1988) The European Challenge: 1992 The benefits of a single market. Wildwood house, Albershort.

COMMISSION of European Community 1988 the Economics of 1992, European Economy No 35, Brussels, Luxembourg.

COMMISSION of the European Community (1993) Growth, Competitiveness,

EMPLOYMENT: The Challenges and ways forward into the 21st century, Supplement

6/93 Brussels, Luxembourg.

CROSLAND C.A.R, (1967) The future of Socialism, Cape, London

CUTLER T. ET AL, (1989) 1992: The Struggle for Europe, Berg Publishers, Oxford.

GALBRAITH J.K., (1993) The Contended Society, Penguin Harmonsdworth, Hants.

GORDON R., (1990) What is New Keynesian Economics? Journal of Economic Literature 28 pp 241-257.

GRIEVE SMITH J AND MICHIE J., (1994), Unemployment in Europe Academic Press, London. 
HOLMLUND B and LOFGREN (ED)., (1990) Unemployment and Wage Determination in Europe, Basil Blackwell, Oxford.

INTERNATIONAL LABOUR ORGANISATION (1995) ILO Report 1995, ILO, London. LAYARD D., (1986) How to beat Unemployment

NEUBERGER H., (1989)The Economics of 1992, Socialist Group European Parliament, Luxembourg.

OECD, (1994) The OECD Jobs Study, Paris, OCED.

ROMER D, (1993) The New Keynesian Synthesis - Journal of Economics Perspectives No. 7 pp. 6-14.

THERBORN G., (1986) Why Some People Are More Unemployed Than Others: The Strange Paradox of Growth and Unemployment, Verso, London.

TEAGUE P., (1994), Between New Keynesianism and Deregulation: Employment Policy in the European Union, Journal of European Public Policy Vol1 No3 pp314-345. RIFKIN J., (1995), The End of Work, New York Press.

SYMES V., (1996) Unemployment in Europe, Routledge, London.

Dr Maurice Mullard, is Professor of Social Policy, University of Hull, U.K. 